\title{
PERLINDUNGAN HUKUM BAGI KREDITOR DARI PENYALAHGUNAAN BARANG JAMINAN OLEH DEBITOR DALAM PERJANJIAN KREDIT USAHA
}

\author{
Marconery Yadev, Paramita Prananingtyas, Anggita Doramia Lumbanraja \\ Program Studi Magister Kenotariatan, Universitas Diponegoro \\ Fakultas Hukum, Universitas Diponegoro \\ Email:mny248055@gmail.com
}

\begin{abstract}
The existence of fiduciary can help obtain venture capital for the community through credit and help develop the global economy. Fiduciary with a guarantee of inventory, has not protected the interests of banks that provide credit assistance to the public (debtors). The problem that often arises in fiduciary guarantees is the legal protection of collateral. There are often cases where creditors default on misusing Debtor's collateral without permission. The problem examined in this study is about how the legal protection for creditors in granting business loans with goods collateral and about what factors hinder the legal protection of fiduciary guarantees with objects of collateral. This research is a normative jurisdiction research. The results, legal protection in granting business loans with collateral for goods which were loaded with fiduciary, consisting of repressive legal protection, and preventive legal protection. Inhibiting factors in legal protection for those who receive fiduciary guarantees with the object of collateral inventory burdened of the articles in Law Number 42 of 1999, the completion of the legal process is long process, with the threat of punishment, there is no collaboration with relevant, the execution is difficult to realize because they still have to ask for the fiduciary approval.
\end{abstract}

\section{Keywords: fiduciary guarantee; creditors; legal protection}

\begin{abstract}
Abstrak
Keberadaan fidusia dapat membantu memperoleh modal usaha bagi masyarakat melalui kredit dan membantu perkembangan ekonomi secara global. Fidusia dengan jaminan benda persediaan, belum melindungi kepentingan bank yang memberikan bantuan kredit kepada masyarakat (debitor). Permasalahan yang kerap timbul dalam jaminan fidusia adalah mengenai perlindungan hukum terhadap barang jaminan. Dewasa ini, sering ditemui kasus-kasus dimana kreditor melakukan wanprestasi menyalahgunakan barang jaminan milik Debitor tanpa izin sehingga merugikan kepentingan. Penelitian ini mengkaji perlindungan hukum bagi kreditor dalam pemberian kredit usaha dengan jaminan barang dan faktor-faktor apa yang menghambat dalam perlindungan hukum bagi penerima jaminan fidusia dengan objek jaminan barang. Penelitian ini merupakan penelitian yuridisi normatif. Hasil penelitian menunjukkan, Perlindungan hukum kreditor dalam pemberian kredit usaha dengan jaminan barang persediaan yang dibebani dengan fidusia, terdiri dari Perlindungan hukum represif, dan Perlindungan hukum preventif. Faktor-faktor yang menghambat dalam perlindungan hukum bagi yang menerima jaminan fidusia dengan objek jaminan barang persediaan yang dibebani dengan fidusia di dalam praktek perbankan saat ini adalah inkonsistensi pasal-pasal Undang-Undang Nomor 42 Tahun 1999, penyelesaian jalur hukum denga hukuman yang tidak seberapa, tidak adanya kerjasama dengan instansi yang berwenang, serta pelaksanaan eksekusi yang sulit terealisasi karena masih meminta persetujuan pemberi fidusia atau pelelangan umum.
\end{abstract}

Kata kunci : jaminan fidusia; kreditor; perlindungan hukum 


\section{A. Pendahuluan}

Pelaksanaan penjaminan untuk memperoleh pinjaman oleh kreditor telah dikenal hukum jaminan untuk benda tidak bergerak dan benda bergerak. Untuk benda tidak bergerak menggunakan lembaga jaminan fidusia yang diatur dalam Undang-Undang Nomor 42 Tahun 1999 tentang Jaminan Fidusia.

Jaminan fidusia merupakan salah satu cara bagi para debitor yang hanya memiliki barang barang yang ia gunakan sendiri untuk menjalankan mata pencaharian atau setidaknya tetap memerlukan barang itu dalam penguasaannya, yang dapat dijadikan sebagai barang jaminan. Selain itu jika diperuntukkan untuk menambah modal usaha maka ia harus menggunakan barang tersebut untuk jaminan kredit pada bank(Palgunadi, 2006).

Fidusia (Fidusia Eigendoms Overdracht) adalah pengalihan kepemilikan, berdasarkan kepercayaan. Perkataan "fiducia" berarti "kepercayaan", yakni salah satu pihak memberikan kepercayaan penuh (memberikan kuasa) kepada pihak lain untuk mengalihkan hak miliknya, namun benda-benda yang dijadikan jaminan tersebut merupakan jaminan utang.(Sutedi, 2006)

Barang-barang yang dapat dijadikan jaminan dengan lembaga jaminan fidusia diantaranya adalah benda persediaan (inventory) yang selalu berubah-ubah dan atau tidak tetap, seperti stok bahan baku, barang jadi, atau portofolio perusahaan efek.

Untuk benda persediaan yang dijadikan jaminan fidusia, apabila benda persediaan tersebut digunakan maka harus mengganti dengan benda yang nilainya sama, dan benda pengganti tersebut harus didaftarkan lagi sebagaimana benda persediaan yang dijadikan jaminan sebelumnya. Tentunya hal tersebut tidak efektif. Selain itu, benda persediaan sangat sulit dalam pengawasannya, karena setiap saat benda persediaan tersebut digunakan sewaktu-waktu, kreditor tidak dapat setiap saat mengawasi benda persediaan tersebut.

Di satu sisi, keberadaan fidusia dapat membantu memperoleh modal usaha bagi masyarakat melalui kredit dan membantu perkembangan ekonomi secara global, tetapi di sisi lain fidusia dengan jaminan benda persediaan, belum dapat melindungi kepentingan bank selaku kreditor yang memberikan bantuan kredit kepada masyarakat (debitor), karena benda-benda persediaan tersebut sewaktu-waktu dapat digunakan oleh debitor dalam proses usahanya, dan kreditor tidak dapat sewaktu-waktu mengawasi penggunaan benda persediaan yang telah dijaminkan tersebut. (Abdullah, 2008) Hal yang dikhawatirkan karena tanpa sepengetahuan kreditor, dapat saja debitor menggunakan benda persediaan yang telah dijaminkan tersebut tanpa memberitahukan terlebih 
dahulu, sehingga di sini debitor telah melakukan wanprestasi atau debitor mengalihkan benda persediaan tersebut kepada pihak lain, sehingga akan menimbulkan konflik antara kreditor dan debitor.

Perbuatan debitor tersebut, tentunya merugikan pihak kreditor. Penyalahgunaan benda jaminan fidusia akan menimbulkan pelanggaran hukum dan sengketa, sehingga perlu menindak debitor yang melakukan pelanggaran hukum tersebut sesuai dengan Undang-Undang Nomor 42 Tahun 1999, jadi tidak akan ada lagi debitor yang merugikan kreditor.(Prajitno, 2009)

Sebagaimana diketahui bahwa lembaga jaminan merupakan salah satu bentuk perlindungan hukum bagi kreditor apabila debitor ingkar janji, tidak memenuhi kewajibannya sesuai yang diperjanjikan (wanprestasi) dalam melunasi utang kreditnya. Melihat rentannya benda persediaan sebagai objek jaminan fidusia yang dapat digunakan sewaktu-waktu oleh debitor dan kurangnya pengawasan dari pihak kreditor, maka perlu adanya upaya agar kreditor mendapatkan perlindungan hukum dalam lembaga jaminan fidusia dengan objek benda persediaan sebagai jaminan utang.

Prinsip itikad baik (Good faith) menjadi asas yang paling penting dan mendasar dalam hukum kontrak (hukum perjanjian). Prinsip itikad baik ini membatasi kebebasan berkontrak dan kekuatan mengikatnya suatu perjanjian.(Khairandy, 2003). Menurut penulis, prinsip Itikad baik para pihak dalam melakukan perjanjian harus diterapkan dengan memperhatikan kepatutan. Setiap perjanjian harus didasarkan pada alasan dan keadilan sehingga timbul keseimbangan terhadap keuntungan dan kerugian kepada para pihak dalam suatu perjanjian.

Atas dasar latar belakang tersebut di atas, maka yang menjadi permasalahan yang dikaji dalam penelitian ini adalah mengenai bagaimana perlindungan hukum bagi kreditor dalam pemberian kredit usaha dengan jaminan barang dan mengenai faktor-faktor apa yang menghambat dalam perlindungan hukum bagi penerima jaminan fidusia dengan objek jaminan barang.

Ada beberapa penelitian terdahulu yang membahas mengenai jaminan fiudsia. Pada tahun 2017 Ninik Meiyudianti meneliti tentang kewajiban kreditor atas jaminan fidusia yang telah dilunasi debitor, dan mengenai tanggung gugat kreditor atas kelalaian melakukan roya pada jaminan fidusia yang telah lunas. Adapun Roya adalah tugas kreditor untuk melaporkan atas hapusnya hutang kepada kantor pendaftaran fidusia untuk dilakukan pencoretan pencatatan jaminan fidusia danapabila tidak dilakukan oleh kreditor tentunya akan berdampak kepada debitor yaitu tidak dapat menjadikan benda yang dimilikinya tersebut sebagai obyek jaminan fidusia pada saat debitor akan melakukan perjanjian kredit dengan pihak lain setelah dilunasinya hutang yang lama.(Meiyudianti, 
2017). Persamaan dengan penelitian ini adalah bahwa sama - sama meneliti mengenai kewajiban kewajiban yang timbul atas pelunasan hutang oleh debitor. Dan perbedaannya ialah bahwa dalam penelitian ini akan menggambarkan lebih lanjut mengenai bentuk penyelesaian secara hukum dari pelanggaran-pelanggaran atas pelaksanaan kewajiban tersebut.

Pada tahun 2018, Yuoky Surinda meneliti tentangPerlindungan Hukum Bagi Pihak Kreditor Dalam Perjanjian Kredit Dengan Jaminan Fidusia, penelitian ini menjelaskan mengenai cara-cara pencegahan agar debitor tidak melakukan perbuatan-perbuatan yang dapat merugikan kepentingan para kreditor, yaitu pada saat debitor dinyatakan pailit, debitor tidak lagi memiliki kewenangan untuk mengurus, memindahtangankan harta kekayaannya yang telah berubah status hukumnya menjadi harta pailit (Surinda, 2018). Sedangkan dalam penelitian ini penulis menjelaskan dari sisi kreditor, seperti bagaimana para kreditor dapat mengetahui perlindungan hukum dalam kegiatan pemberian kredit usaha dengan jaminan barang persediaan yang dibebani dengan fidusia.

PadaTahun 2017, AdrianusVivi Lia Falini Tanjung meneliti tentang Implementasi asas-asas umum hukum kebendaan terhadap implementasi hak tanggungan, hak fidusia, hipotek, dan hak gadai dalam jaminan fidusia, yakni Asas publicitet, Asas specialitet, Asas tak dapat dibagi-bagi, dan Asas inbezittstelling yaitu barang jaminan (gadai) harus berada pada penerima gadai(Tanjung, 2017). Dan dalam penelitian ini, penulis akan membahas bagaimana Implementasi dari asas umum hukum kebendaan diatas dalam pelaksanaan Hukum atau peratutan perundang-undangan terkait dengan Jaminan Fidusia.

\section{B. Metode Penelitian}

Penelitian ini merupakan penelitian yuridis normative yaitu Peneliti melakukan studi kepustakaan denga nmeneliti dari bahan-bahan hukum sekunder yakni berupa jurnal, tesis, disertasi, buku-buku yang terkait mengenai jaminan fidusia. Selain itu Peneliti juga menggunakan bahan hukum primer yakni berupa Peraturan perundang-undangan, turut pula dikaji dalam penelitian ini yakni meliputi :Undang-Undang Nomor 42 Tahun 1999 Tentang Jaminan Fidusia, Peraturan Pemerintah Nomor 86 Tahun 2000 Tentang Permohonan, Pendaftaran Fidusia Dilakukan Oleh Penerima Fidusia, Kuasa, Atau Wakilnya Pada Kantor Pendaftaran Fidusia, Peraturan Pemerintah Nomor 75 Tahun 2005 Tentang Jenis Dan Tarif Atas Jenis Penerimaan Negara Bukan Pajak, Peraturan Pemerintah Nomor 21 Tahun 2015 Tentang Tata Cara Pendaftaran Jaminan Fidusia Dan Biaya Pembuatan Akta Jaminan Fidusia, Peraturan 
Kepala Kepolisian Negara Republik Indonesia Nomor 8 Tahun 2011 Tentang Pengamanan Eksekusi Jaminan Fidusia.

\section{Hasil Dan Pembahasan}

\section{Tinjauan Yuridis Perlindungan Hukum Bagi Kreditor Dari Penyalahgunan Barang} Jaminan yang dilakukan oleh Debitor dalam Perjanjian Kredit Usaha

Marulak Pardede dalam laporan akhir penelitian tentang Implementasi Jaminan Fidusia dalam Pemberian Kredit di Indonesia Tahun 2006 menyatakan Objek jaminan yang dapat dibebani dengan fidusia, salah satunya adalah barang persediaan (inventory atau stock barang) yang baik pada kualitas maupun cukup pada kuantitas, dan barang tersebut dapat berupa barang dagangan maupun barang dalam proses produksi (setengah jadi atau barang jadi). Stock barang yang merupakan jaminan kredit memiliki tingkat risiko tinggi dikarenakan perputarannya yang cepat. Dan agar marjin jaminan dapat menutupi risiko kredit, laporan stock barang harus dilakukan secara berkala seperti sekali dalam satu bulan atau tiga bulan ataupun enam bulan.(Pardede, 2006)

Irma Devita Purnamasari mengemukakan tentang pentingnya pembuatan daftar atau list stock setiap barang dagangan yang akan dijaminkan, daftar tersebut memuat lokasi dimana barang dagangan tersebut disimpan, serta daftar tersebut harus dilaporkan secara berkala atau diperbarui biasanya tiga bulan sekali. Hal ini dikarenakan sifatnya yang tidak tetap (dapat diperjualbelikan).(Purnamasari, 2014)

Belum ada peraturan resmi yang menyatakan bahwa setiap pem-baruan yang menyatakan bahwa setiap pembaruan daftar piutang atau tagihan dan daftar stok barang harus didaftarkan kembali ke kantor fidusia setempat. pada waktu kali pertama pemberian jaminan fidusia. Pendaftaran cukup dilakukan satu kali saja, Perubahan daftar hanya perlu disimpan oleh penerima fidusia selaku kreditor untuk keperluan eksekusi pada waktu debitor wanprestasi.

Pendaftaran jaminan fidusia diatur dalam Pasal 11 sampai dengan Pasal 18 UndangUndang Nomor 42 Tahun 1999 tentang Jaminan Fidusia dan Peraturan Pemerintah Nomor 86 Tahun 2000 tentang Tata Cara Pendaftaran Jaminan Fidusia dan Biaya Pembuatan Akta Jaminan Fidusia, Dalam Pasal 11 Undang-Undang Nomor 42 Tahun 1999 ditentukan bahwa benda, baik yang berada di dalam wilayah negara Republik Indonesia maupun berada di luar wilayah negara Republik Indonesia yang dibebani jaminan fidusia wajib didaftarkan. Pendaftaran dilakukan pada Kantor Pendaftaran Fidusia. 
Prosedur dalam pendaftaran jaminan fidusia, sebagaimana yang diatur dalam Pasal 11 sampai dengan Pasal 18 Undang-Undang Nomor 42 Tahun 1999 dan Peraturan Pemerintah Nomor 86 Tahun 2000, yaitu: Permohonan pendaftaran fidusia dilakukan oleh penerima fidusia, kuasa, atau wakilnya pada Kantor Pendaftaran Fidusia. Permohonan itu diajukan secara tertulis dalam bahasa Indonesia. Permohonan pendaftaran itu dengan melampirkan pernyataan pendaftaran fidusia.

Kantor Pendaftaran Fidusia mencatat jaminan fidusia dalam buku daftar fidusia pada tanggal yang sama dengan tanggal penerimaan permohonan pendaftaran.

Membayar biaya pendaftaran fidusia. Dalam banyak kasus dan dalam praktik perbankan, jaminan fidusia memang tidak efektif, terutama jaminan fidusia yang berupa barang persediaan (inventory). Oleh karena sekalipun secara teoretis suatu barang persediaan yang telah dijual, hak preferen kreditor tidak mengikuti benda tersebut, namun hasil dari penjualannya wajib digunakan untuk melunasi fasilitas kredit atau untuk membeli benda yang sejenis dengan kualitas dan kuantitas yang sama dan dijadikan sebagai barang persediaan kembali.

Pengalihan objek jaminan fidusia (dalam bentuk menjual atau menyewakan) untuk menjaga kepentingan penerima fidusia dapat dilakukan oleh pemberi fidusia, dengan syarat bahwa benda yang dialihkan harus diganti dengan benda yang setara baik dalam nilai maupun jenisnya.(Widiyono, 2009)

Dalam praktik, ketika fasilitas kredit dalam kolektibilitas macet, maka seluruh benda persediaan tersebut sudah habis, sehingga tidak dimungkinkan untuk dilakukan penjualan guna melunasi fasilitas kredit yang dijamin dengan benda tersebut. Kelemahan lain adalah barang per-sediaan yang terjual akan menimbulkan piutang dagang, dan piutang dagang inilah kemudian diikat dengan jaminan fidusia. Berdasarkan sifatnya, piutang dagang selalu akan berubah setiap waktu. Piutang dagang yang saat ini telah diikat dengan jaminan fidusia, maka jika terdapat perubahan mengenai hal tersebut (lampiran akta pemberian jaminan fidusia) wajib dilakukan pendaftaran kembali/pendaftaran ulang. Jika ketentuan ini akan diikuti oleh penerima jaminan fidusia (kreditor), maka pihak kreditor akan selalu sibuk untuk melakukan pengikatan ulang karena barangkali setiap hari terdapat perubahan piutang dagang, yang tentunya hal ini sangat tidak efektif.

Jika debitor mengalihkan barang persediaan tersebut tanpa sepengetahuan dan tanpa persetujuan atau kesepakatan kreditor, atau menggunakan barang persediaan tersebut tetapi tidak mengganti dengan barang persediaan yang setara, maka debitor telah melakukan wan- 
prestasi atau cidera janji. Hukum memberikan solusi terhadap persoalan wanprestasi tersebut, para pihak yang dirugikan dapat mengajukan beberapa gugatan berikut ini : pemenuhan perikatan, pemenuhan perikat-an dengan ganti rugi, pembatalan persetujuan timbal balik, dan pem-batalan dengan ganti rugi.

Pemberian fidusia yang mengalihkan, menggadaikan, atau menyewakan benda yang menjadi objek fidusia, dalam hal ini adalah barang persediaan dan tanpa persetujuan tertulis terlebih dahulu dari penerima fidusia maka perbuatan pemberi fidusia tersebut sudah termasuk dalam tindak pidana dan dapat dikenai dengan sanksi pidana.

\section{Faktor-faktor yang menghambat dalam perlindungan hukum bagi penerima jaminan} fidusia dengan objek jaminan barang

Meskipun telah diatur dalam Undang-Undang No. 42 Tahun 1999, pada saat pelaksanaan jaminan fidusia masih sering ditemukan pelanggaran-pelanggaran hukum baik oleh pihak debitor maupunpihak kreditor, Adapun penyebab terjadinya pelanggaran tersebut biasanya ialahkarena jaminan fidusia masih dianggap lembaga yang paling gampang dilakukan oleh semua orang karena pengalihan hak itu didasarkan atas kepercayaan.(Kulas, 2020)

Berdasarkan Pasal 35 dan Pasal 36 Undang-undang Nomor 42 Tahun 1999, pelanggaran hukum yang dilakukan debitor terhadap jaminan fidusia dapat dituntut melalui hukum pidana. Terhadap perjanjian jaminan yang dibuat secara legal apabila debitor mengalihkan benda atau objek jaminan tanpa sepengetahuan kreditor maka debitor dapat dilaporkan atas tuduhan penggelapan sesuai pasal 327 KUHP dan pada perjanjian jaminan secara legal objek jaminan fidusia wajib untuk disebutkan secara jelas di dalam akta jaminan fidusia tersebut, baik identifikasi (spesifikasi dan ciri-ciri penting) benda tersebut maupun penjelasan surat bukti kepemilikannya dan bagi benda inventory yang selalu berubah-ubah, tetap harus dijelaskan jenis benda dan kualitasnya di dalam akta jaminan fidusia. Dan apabila debitor mengalihkan objek jaminan perjanjian fidusia yang dibuat di bawah tangan, debitor tersebut tidak dapat dijerat atau dituntut menggunakan Undang - Undang Fidusia. Tetapi hal tersebut dapat melemahkan posisi kreditor dalam melaksanakan hak eksekutorialnya.(Ismail, 2011)

Hal tersebut berbeda dengan pelanggaran oleh kreditor, bahwa belum adanya pengaturan sanksi pidana terhadap kreditor yang tidak melaksanakan kewajibanya berupa mendaftarkan barang yang menjadi objek jaminan fidusia ke kantor fidusia. Sementara itu mendaftarkan barang yang menjadi objek jaminan fidusia ke kantor fidusia merupakan hal 
yang sangat penting untuk dilakukan karena apabila tidak dilakukanakan menimbulkan potensi besar kerugian keuangan danpendapatan negara yang seharusnya diterima dalam bentuk PNBP (Penerimaan Negara Bukan Pajak)berdasarkan Peraturan Pemerintah Republik IndonesiaNomor 28 Tahun 2019TentangJenis dan Tarif Atas Jenis PenerimaanNegara Bukan Pajak yang Berlaku Pada Kementerian Hukum Dan Hak Asasi Manusia.(Putri, 2018)

Selanjutnya dengan melaksanakan pendaftaran jaminan fidusia berarti telah memenuhi unsur publisitas, sehingga dapat dikontrol dan dapat menghindari terjadinya hal-hal tidak sehat dalam praktik, seperti adanya fidusia dua kali atau fidusia ulang tanpa sepengetahuan kreditornya, atau adanya pengalihan objek jaminan fidusia tanpa se-pengetahuan kreditor(Fuady, 2000). Dan dengan melaksanakan pendaftaran objek jaminan fidusia di kantor Kantor Pendaftaran Fidusia (KPF) maka kreditor atau penerima fidusia memperoleh hak preferensi, yaitu hak dimana Kreditor yang mendaftarkan jaminan yang ia terima akan menjadi Kreditor tersebut berkedududkan lebih utama dari Kreditor lainya.

Dalam pelaksanaan perjanjian fidusia dengan jaminan persediaan, debitor yang tidak mempunyai itikad baik mengalihkan barang persediaan tanpa sepengetahuan kreditor, atau barang persediaan berkurang jumlahnya. Bahwa barang persediaan yang digunakan sebagai jaminan dapat berkurang jumlahnya dikarenakan barang rusak dan sebagian dicuri oleh karyawan. Perusahaan mempunyai itikad baik untuk mengganti barang persediaan yang sudah berkurang jumlahnya, tapi sementara ini belum mempunyai modal untuk mengganti barang persediaan tersebut. Perusahaan sebagai debitor mengetahui apabila tidak mengganti barang jaminan (barang persediaan) yang diguna-kan, termasuk ke dalam perbuatan melanggar hukum. Apabila perusahaan sudah tidak mampu membayar utang dan mengganti barang persediaan yang berkurang tersebut, maka perusahaan meminta keringanan pembayaran pada kreditor (perbankan).

Konflik norma dan norma yang kabur dalam pasal-pasal Undang-Undang Nomor 42 Tahun 1999 diuraikan sebagai berikut :

\section{a. Konflik Norma}

Pada pasal 2 Undang-Undang Jaminan Fidusia (UUJF) yang berbunyi, bahwa "Undangundang ini berlaku terhadap setiap perjanjian yang bertujuan untuk membebani Benda dengan Jaminan Fidusia".Mengindikasikan bahwa pasal ini berusaha memberi kepastian hukum, menyatakan bahwa UUJF tersebut merupakan dasar hukum untuk melaksanakan Jaminan Fidusia, serta mampu memberi rasa terlindungi olehh ukum bagi pihak yang 
berkepentingan. Namun hal tersebut bertentangan dengan Pasal Pasal 37 ayat (1) yang berbunyi : "Pembebanan Benda yang menjadi objek Jaminan Fidusia yang telah ada sebelum berlakunya Undang-undang ini, tetap berlaku sepanjang tidak bertentangan dengan undang-undang ini."danPasal 38 UUJF yang berbunyi "Sepanjang tidak bertentangan dengan ketentuan dalam Undang-undang ini,semua peraturan perundangundangan mengenai Fidusia tetap berlaku sampai dengan dicabut, diganti, atau diperbaharui." Kedua pasal tersebut mengindikasikan bahwa UUJF tersebut memberi ruang tetap berlakunya peraturan yang lama (berlaku surut) sebelum UU No. 42 tahun 1999 tersebut diundangkan untuk dijadikan dasar hukum pelaksanaan Jaminan Fidusia, dan hal tersebut bertentangan dengan asas hukum Lex posterior derogat legi priori. Serta pasal tersebut juga membuka potensi untuk kreditur tidak melaksanakan pendaftaran fidusia meskipun peraturan baru telah mengatur.

Selanjutnya terkait dengan Parate Eksekusi (hak eksekusi sepihak oleh Kreditor tanpa melewati hakim) yang dilakukan kepada objek jaminan fidusia juga terdapat kontra norma, yaitu dengan dikeluarkannya Peraturan Kepala Kepolisian Negara Republik Indonesia Nomor 8 Tahun 2011 tentang Pengamanan Eksekusi Jaminan Fidusia, seolaholah setiap eksekusi dari jaminan fidusia harus diamankan oleh pihak kepolisian dan hal ini tidak selaras dengan ketentuan dalam UUJF, yaitu apabila debitor melakukan wanprestasi atau cidera janji, maka sesuai berdasarkan perjanjian kredit yang dilakukan antara pihak kreditor dan debitor, maka kreditor dapat melakuakan eksekusi terhadap objek yang dijaminkan, dan pelaksanaan eksekusi tersebut sesuai dengan Pasal 15 dan Pasal 29 ayat (1) Undang-Undang Jaminan Fidusia.Eksekusi oleh kreditor tersebut tidak boleh dilakukan dengan cara paksaan atau ancaman, seperti yang dilakukan oleh debt collector dengan mengambil paksa setiap objek yang dijaminkan oleh debitor,karena jika hal tersebut dilakukan maka kreditor dapat dikenakan Pasal 368 KUHP.(Ibrahim, 2004)

\section{b. Norma Yang Kabur (varge normen)}

Norma yang kabur dapat ditemukan dalam pengaturan Pasal 11 ayat (1) Undang-Undang Nomor 42 Tahun 1999 dan Pasal 12 ayat (1). Pasal 17 Undang-Undang Nomor 42 Tahun 1999 melarang adanya fidusia ulang. Terjadi kekaburan antara apa yang disebut pendaftaran "benda" jaminan fidusia, yang dimaksud dalam Pasal 11 ayat (1) dan pendaftaran "jaminan” fidusia seperti yang dimaksud dalam Pasal 12 ayat (1). Maksud fidusia ulang menurut Penjelasan Undang-Undang Nomor 42 Tahun 1999 adalah fidusia 
ulang oleh pemberi fidusia,(Badrulzaman, 1983) baik debitor maupun penjamin pihak ketiga tidak dimungkinkan atas benda yang menjadi objek jaminan fidusia karena hak kepemilikannya atas benda tersebut telah beralih kepada penerima fidusia. Padahal, hak milik tidak beralih, Hanya sebagian dari hak kepemilikan yang beralih sesuai Pasal 1 ayat (1), dan hal ini sebenarnya dapat difidusia ulang kepada kreditor yang sama maupun kepada kreditor yang berbeda sebagaimana terjadi pada kredit sindikasi, dalam rangka pembiayaan kredit konsorsium karena pem-berian nilai kreditnya masih di bawah dari nilai benda jaminannya.

\section{Simpulan}

Perlindungan hukum bagi kreditor dalam pemberian kredit usaha dengan jaminan barang persediaan yang dibebani dengan fidusia, terdiri dari : Perlindungan hukum represif, yakni melalui: Penyelamatan kredit melalui rescheduling, restructuring, reconditioning, kombinasi, dan eksekusi dan penjualan agunan melalui pelelangan umum maupun fiat pengadilan, Perlindungan hukum preventif, yakni melalui; Pemberian kredit oleh kreditor harus berdasarkan prinsip kehati-hatian dengan melakukan analisa kredit, Pembebanan pendaftaran jaminan fidusia; serta Pengecekan melalui BI Checking, Batas Maksimum Pemberian Kredit (BMPK),

Faktor-faktor yang menghambat dalam perlindungan hukum bagi yang menerima jaminan fidusia dengan objek jaminan barang persediaan yang dibebani dengan fidusia di dalam praktek perbankan saat ini adalah : (a) inkonsistensi pasal-pasal dalam Undang-Undang Nomor 42 Tahun 1999, (b) penyelesaiannya jalur hukum prosesnya sangat panjang, dengan ancaman hukuman yang tidak seberapa, (c) tidak adanya kerjasama dengan instansi yang berwenang dan terkait, serta (d) pelaksanaan eksekusi yang sulit terealisasi karena masih harus meminta persetujuan pemberi fidusia atau melalui pelelangan umum.

\section{DAFTAR PUSTAKA}

\section{Buku-buku:}

Abdullah. (2008). Pertimbangan Hukum Putusan Pengadilan. Sidoarjo: Program Pascasarjana Universitas Sunan Giri.

Badrulzaman, M. D. (1983). Perjanjian Kredit Bank. Bandung: Alumni.

Fuady, M. (2000). Jaminan Fidusia. Bandung: Citra Aditya Bakti.

Ibrahim, J. (2004). Cross Default \& Cross Collateral, Sebagai Upaya Penyelesaian Kredit Bermasalah. Bandung: Refika Aditama. 
Ismail. (2011). Manajemen Perbankan, Dari Teori Menuju Aplikasi. Jakarta: Kencana Prenada Media Group.

Khairandy, R. (2003). Iktikad Baik dalam Kebebasan Berkontrak. Jakarta: Universitas Indonesia.

Palgunadi, P. (2006). Jaminan-Jaminan Untuk Pemberian Kredit Menurut Hukum Indonesia. Bandung: Citra Aditya Bakti.

Prajitno, A. A. A. (2009). Hukum Fidusia, Problematika Yuridis Pemberlakuan Undang-Undang Nomor 42 Tahun 1999 (Edisi Pert). Malang: Bayumedia Publishing.

Purnamasari, I. D. (2014). Panduan Lengkap Hukum Praktis Populer : Kiat-Kiat Cerdas, Mudah, Dan Bijak Memahami Masalah Hukum Jaminan Perbankan. Bandung: Kaifa.

Putri, A. S. (2018). Eksekusi Jaminan Fidusia yang Tidak Didaftarkan Oleh PT Sinar Mitra Sipadan Finance (Studi Putusan Nomor 2467 K/Pdt/2015). Jakarta: Universitas Islam Negeri Syarif Hidayatullah.

Sutedi, A. (2006). Implikasi Hak Tanggungan Terhadap Pemberian Kredit Oleh Bank Dan Penyelesaian Kredit Bermasalah. Jakarta: Cipta Jaya.

Widiyono, T. (2009). Agunan Kredit Dalam Financial Engineering, Panduan Bagi Analisis Kredit Dan Perbankan, Business Structure As A Push On Financial Engineering And Law As A Contiguous Nature Of Business. Bogor: Ghalia Indonesia.

\section{Artikel Jurnal}

Kulas, F. A. (2020). Dasar Tuntutan Pidana Dalam Sengketa Jaminan Fidusia Menurut UndangUndang Nomor 42 Tahun 1999. Lex Privatum, Vol VIII/No.1/Jan-Mar/2020.

Meiyudianti, N. (2017). Akibat Hukum Kelalaian Kreditur Dalam Melakukan Roya Atas Jaminan Fidusia. (Fakultas Hukum, Universitas Narotama Surabaya).

Surinda, Y. (2018). Perlindungan Hukum Bagi Pihak Kreditur Dalam Perjanjian Kredit Dengan Jaminan Fidusia. (Stikes Payung Negeri Pekanbaru, Riau).

Tanjung, V. L. F. (2017). Implementasi Asas-Asas Umum Hukum Kebendaan Dalam Undang Undang Nomor 42 Tahun 1999 Tentang Jaminan Fidusia. (Universitas Muhammadiyah Sumatera Utara).

S. Solechan, "Pengawasan Pelaksanaan Sistem Outsourcing yang Berbasis Pada Hak Asasi Manusia," Administrative Law \& Governance Journal, vol. 2, no. 2, pp. 337 -348, Jun. 2019. https://doi.org/10.14710/alj.v2i2.337 -348

\section{Sumber Online:}

Pardede, M. (2006). Implementasi Jaminan Fidusia dalam Pemberian Kredit di Indonesia. Retrieved from 
https://www.bphn.go.id/data/documents/implementasi_jaminan_fidusia_dalam_pemberian _kredit_di_indonesia..pdf

\section{Peraturan Perundang-undangan}

Undang-Undang Nomor 42 Tahun 1999 Tentang Jaminan Fidusia.

Peraturan Kepala Kepolisian Negara Republik Indonesia Nomor 8 Tahun 2011 Tentang Pengamanan Eksekusi Jaminan Fidusia.

Peraturan Pemerintah Nomor 86 Tahun 2000 Tentang Tata Cara Pendaftaran Jaminan Fidusia Dan Biaya Pembuatan Akta Jaminan Fidusia.

Peraturan Pemerintah Nomor 75 Tahun 2005 Tentang Jenis Dan Tarif Atas Jenis Penerimaan Negara Bukan Paja.

Peraturan Pemerintah Nomor 86 Tahun 2000, Yaitu : Permohonan Pendaftaran Fidusia Dilakukan Oleh Penerima Fidusia, Kuasa, Atau Wakilnya Pada Kantor Pendaftaran Fidusia. 